\title{
TÓZSA ISTVÁN: A TÉRINFORMATIKA ALKALMAZÁSA A TERMÉSZETI ÉS HUMÁN ERŐFORRÁS GAZDÁLKODÁSBAN
}

\author{
(Aula Kiadó, Budapest, 2001, 180 o.) \\ EDELÉNYI BÉLA
}

Magyarországon kevés olyan szakkönyv került kiadásra, amely a térinformatika széles körủ gyakorlati alkalmazását próbálja meg bemutatni. Dr. Tózsa István ezt a hiányt pótolta egy olyan kiadvánnyal, amely egyaránt alkalmas a térinformatika felhasználásának módszereire és az oktatására is.

A könyv 180 oldalon keresztül, gazdag térképi ábrázolással, színes mellékletekkel mutatja be a térinformatika felhasználhatóságát. Külön előnye, hogy kivétel nélkül hazai példákat emel ki. A fejezetek felépítése egységes, minden fejezet után a témához kapcsolódó hazai illetve idegen nyelvủ irodalmat ad meg. Fejezetenként ellenörző kérdéseket fogalmaz meg, amelyek alkalmassá teszik a kiadványt oktatási segédanyagként történö hasznosításra is.

A könyv felépitése területi jellegü, az országos kutatásokon keresztül a regionális, megyei, városi vizsgálatokon keresztül a kerületekig lebontva. Külön kiemelést érdemel a régióközi kapcsolatokat bemutató fejezet.

A fejezetek többsége a Magyar Tudományos Akadémia Földrajztudományi Kutató Intézetének keretén belül történt kutatások térinformatikai jellegü eredményeit mutatja be. A bemutatott eredmények az erőforrás-gazdálkodás témakör köré csoportosulnak.

Az első fejezet az országos és megyei kutatásokat mutatja be. Az országos szintủ vizsgálatok közül a felszíni érzékenység és sérülékenység, valamint az ökológiai stabilitás általános kutatási módszereivel ismerkedhetünk meg. Nagyobb lélegzetvételü volt az a kutatás, amelyik az Amerikai Egyesült Államok Környezetvédelmi Hivatala által kidolgozott módszer magyarországi adaptációja volt. A hazai Környezetállapot Regisztráló és Értékelö Program (EMAP) az első volt Európában. A módszer segítségével a vízfolyások egységes mintavételezésével lehet pillanatképet nyerni az ökoszisztéma állapotáról.

Az országos és a megyei felhasználás közötti átmenetet reprezentálja az a kutatás, amely a hegyvidéki, dombvidéki és alföldi erdögazdálkodás, valamint a környezeti savasodás szempontjából felmért szennyeződés - érzékenység - térinformatikai módszereit mutatja be. Az erdőgazdálkodás esetében 54 adottság figyelembevételével határozták meg hat hazánkban uralkodó fafajta települési igényeit. A térinformatika eszközeivel Borsod-Abaúj-Zemplén, Somogy és Jász-Nagykun-Szolnok megyei területeket választottak ki, mint a hazai fafajták telepítésére alkalmas helyeket. Hasonló jellegü, de más célú volt a savas esőkre érzékeny területek kiválasztá$\mathrm{sa}$, amit a környezeti savasodás tényezői alapján végeztek el Vas és Békés megye példáján. Mindkét vizsgálat esetében megfelelő módszertani útmutatót kapunk az 
Tér és Társadalom 16. évf. 2002/2. 163-175. p.

ilyen jellegü kutatások kiindulásához. A megyei területek vizsgálata során a Békés megyei környezeti információs rendszer, illetve Komárom-Esztergom megye terület-felhasználási és vetésszerkezeti térképének elkészítési feladatait mutatja be a szerzö.

A következő fejezet a (mezo)régiók és nagyvárosok erőforrás-gazdálkodásának térinformatikai jellegü megoldásáról szól. Az első témakör szorosan kapcsolódik az előző fejezet utolsó témájához, ugyanis a Komárom-Esztergom megyei vetésszerkezeti térkép további gyakorlati típusú hasznositási lehetőségeire világít rá. A szénhidrogén-lelőhelyek felszíni növényzetre gyakorolt hatását vizsgálta meg az a Duna-Tisza-közének déli részét érintő kutatás, amelyet müholdfelvételek alapján végeztek el 1985-ben az FKI kutatói. A vizsgálat során bebizonyosodott, hogy a térinformatikai módszerek alkalmasak a szénhidrogén elökutatásokban is.

A könyv további részében három téma keretében is Budapest a vizsgált terület. Az első téma az első müholdfelvétel alapján elkészített budapesti területhasznositási térkép módszertanát mutatja be. A második téma a főváros humánökológia minősítésének folyamatát és módszertanát ismerteti meg az olvasóval. A vizsgálat során 15 humánökológiai szempontból fontos tényező figyelembevételével alakították ki Budapest településkörnyezeti besorolását. A harmadik vizsgálat Kelet-KözépEurópa három fővárosának, Bécs, Budapest és Pozsony légszennyezettségi adatainak mủholdfelvételek alapján történő összehasonlitását teszi lehetővé.

Szintén ebben a fejezetben található meg három tájegység vizsgálata is. A Balaton vízminőségét több éve fokozott társadalmi érdeklődés kíséri. Ennek egyik adalékát, a víz klorofiltartamának térinformatikai mérési lehetöségeit mutatja be az esettanulmány. A fejezetben található másik két tanulmány a Dunakanyar és a Bükkalja környezeti terhelhetöségét vizsgálja. Mindkét esetben sikerült olyan terhelhetöségi térképeket elóállítani, amelyek alapján a hosszú távú döntések meghozatalánál a környezetvédelmi szempontokat megfelelöképpen lehet érvényesíteni.

A térinformatika mikroregionális felhasználhatóságára a harmadik fejezetben találhatunk példákat. A települési és kerületi kutatások közül a Csepel-szigeti és a józsefvárosi talajvízfelmérések, valamint három alföldi város (Kecskemét, Gyula és Mezötúr) környezetterhelési vizsgálata kerül bemutatásra. Az utóbbi témával két alfejezet is foglalkozik különböző aspektusokból. Érdekes színfolt a térinformatika felhasználhatóságára az az alfejezet, amely egy síközpont kiválasztásának a módszertanát mutatja be.

Az egészségügyi jellegü kutatásokban való felhasználhatóságra két példát találunk a könyvben. Mindkét példában kerületi példákkal találkozunk, egyszer az alapellátás szervezésére Erzsébetváros és Józsefváros példáján, illetve Ferencváros és Józsefváros ingatlan szintü közegészségügyi térinformatikai rendszerének bemutatására kerül sor. A Földrajzi Információs Rendszer kerületi szintú alkalmazásának további lehetőségeit a belváros ún. „vállalkozásbarát” területeinek kiválasztására szolgáló, illetve a ferencvárosi tesztterületen elvégzett módszertani jellegű kutatás mutatja be. 
$\mathrm{Az}$ utolsó fejezetben a térinformatika régióközi kapcsolatait ismerhetjük meg. A fejezet azért is kívánatos, mert bemutatja azt, hogy a térinformatika a területfejlesztési marketing területén is hasznosítható. A felhozott példa az Észak-magyarországi régió városainak legfontosabb adatait tartalmazó adatbázis felépítésének módszertanát ismerteti meg az olvasóval.

A Dr. Tózsa István által bemutatott kutatások mindegyike a gyakorlati életben többféleképpen hasznosítható. Elsődleges fontosságú a döntés-előkészítésben történő alkalmazhatóság, mind a gazdasági életben (szénhidrogén-lelőhelyek meghatározása, vetésszerkezet kialakítása, erdőtelepítésre alkalmas területek kiválasztása, telephelyválasztás stb.), mind a várostervezésben és területfejlesztésben használható munkákról, illetve módszerekröl van szó. Másodlagos, de nem elhanyagolható a térinformatika monitoring szerepét megalapozó hazai alkalmazási lehetőségek bemutatása.

Az oktatás-kutatás területén a térinformatikai kutatások különbözö témákban és területeken lehetséges kutatási módszereit tárja elénk a szerző. Más tudományágak müvelöi megismerhetik a térinformatikának, mint segédtudománynak az alkalmazási lehetőségeit. A tértudományok oktatása során pedig a könyvet szöveggyüjtemény gyanánt lehet megfelelöen hasznosítani. 